\title{
Cursing the Curse: Nietzsche on the Machiavellianism of Pity Reading The Antichrist 2-7 in Light of Ecce Homo
}

\author{
Thomas Steinbuch ${ }^{1}$
}

Nietzsche's correspondence with his publisher Naumann from November 6, 1888 (KSB 8: 1139) together with his letter to Georg Brandes from November 20, 1888 (KSB 8: 1151) and the drafted letter to Brandes from early December (KSB 8: 1170) show that he wrote Ecce Homo to be the introduction to The Revaluation of All Values, and that he meant it to appear together with The Antichrist. In this letter to Naumann, Nietzsche describes Ecce Homo as being a writing "in the highest degree preparatory" ("im höchsten Grade Vorbereitende Schrift") and that it is "in every sense a long preface" to The Antichrist. He further writes that Ecce Homo must create a real tension ("Spannung") because "im andern Falle geht es wie beim Zarathustra," by which I take him to mean that had we had the preparatory tension of Ecce Homo five years earlier, the poor reception of Thus Spoke Zarathustra would have been averted. With Ecce Homo he will finally be heard, perhaps too much he cautions, and everything will be in order ("und dann wäre Alles in Ordnung"). In his letter of Köselitz of November 13 he says that Ecce Homo is "eine feuerspeiende Vorrede" to the Revaluation, (KSB 8: 1142). Also, the thought that Ecce Homo is the introduction to The Antichrist is implicit in a draft of a letter to Brandes from December 1888: "Zunächst erscheint Ecce Homo..., etc." (KSB 8: 1170). Although Ecce Homo was written to be an autobiographical introduction to what was to be Nietzsche's Hauptwerk, The Revaluation of All V alues, of which The Antichrist was to be volume one, per its onetime subtitle, he dropped that subtitle and settled on "A

\footnotetext{
${ }^{1}$ Thomas Steinbuch, Zhejiang University of Science and Technology - ZUST, China. E-mail: thomas_steinbuch@163.com.

${ }^{2}$ In his editor's introduction to his collection of essays on The Antichrist, Daniel Conway acknowledges that EH is the preface to AC based on the letter to Brandes of November 20, and to Deussen of November 26, and he also cites a letter to Köselitz of October 30 where Nietzsche says that he is worried AC will be confiscated and that EH will avoid that happening. Professor Conway concluded that because the role of EH vis á vis AC was "largely instrumental" as a deflection of censorship it was of less significance to Nietzsche than $\mathrm{AC}$ as $\mathrm{AC}$ contains the revaluation, decoupling the revaluation of AC from the preliminary of stating who he is in $\mathrm{EH}$ in order to put the revaluation before us, which makes the heaviest demand, as not meaning as much to him (!). Also, one wonders why Professor Conway cities the above letters in the foreground for the role of EH to AC and not Nietzsche's letter to Naumann of November 6 where, as would be expected, he goes into much greater detail about the relationship and writes with a high level of intensity, stating that only now will he be heard, and only now "alles ist Ordnung" which in this context, could be read as order of exposition, meaning that the prefatory role of EH is interpretative, and so on, and judge the relationship between the works based on that letter. It is obvious that Nietzsche believed that the role of $\mathrm{EH}$ as introduction served a deep purpose in relation to AC that cannot be conceded "by the way" as Professor Conway does, (Conway 16). Martin Liebscher, who did work from the letter to Naumann of November 6, was surely right to state that Ecce Homo is inseparable from The Antichrist in many ways, (Liebscher, 355f).
}

The Agonist

All rights reserved @ 2021 Transnational Press London 
Curse on Christianity" and abandoned the Revaluation, at least as a literary project. ${ }^{3}$ The Antichrist did not appear until 1895 and Ecce Homo not until 1908, so its intended role as an introduction was never put before the reading public as Nietzsche meant for it to be. ${ }^{4}$

Nietzsche relates several experiences in Ecce Homo, chapter one, "Why I am So Wise," that, it is clear, he intended to serve to introduce sections in The Antichrist. The connections between the sections are undeniable, the topics and wording are sometimes the same; case in point: in his study of the psychological type of Jesus one hardly knows which text the material is from, Ecce Homo or The Antichrist. The concordance from EH from autobiographical specifics of his experience to texts of AC is as follows: Wise/1 on the good fortune/happiness of his existence to $\mathrm{AC} / 2$ which contains the definition of happiness as the feeling that power is growing stronger, the feeling of resistance overcome (see also KSA 13 11[414]; Wise/4, last one-third, and AC 2-7 that gives his critique of pity, which will be my focus at present; Wise/5 where he states that the concept of retaliation is as unapproachable for him ("unzugänglich") as is the concept of equal rights and AC/57 et seq. on the intent of the anarchist and his vengeful psychology of fomenting moral aggrievement thus to produce "wronging" (how "wrong lies not in unequal rights but in the assertion of equal rights"); Wise/ 6 and his experience in periods of decadence that "one does not know how to get free of anything, one does not know how to have done with anything, one does not know how to thrust back - everything hurts," (Hollingdale translation), and how this situation poses one half of the problem of how to achieve freedom from ressentiment (solved by Russian Fatalism) and the analysis of the psychological type of Jesus in AC 28-40. In those sections several of these details are repeated but, more importantly, the overarching theme is the same that the psychology of Jesus is to be discovered in the idea that he sought freedom from ressentiment given a position of weakness, which is the problem posed in Wise/6. Jesus is psychologically a decadent who achieved freedom from ressentiment fatalistically, even by accepting his crucifixion, but he did not solve the problem of becoming free of ressentiment by becoming strong enough to master it, as Nietzsche fills out the rest of the picture in Wise/6. Also, Nietzsche's regimens of choice of place, climate and nutrition in Why I am So Clever line up with his study of Buddhism in The Antichrist as a regime of hygiene.

As just mentioned, I will be focusing on the critique of pity in Ecce Homo, Wise/4, reading it as introducing AC 2-7. In Ecce Homo Wise/4 Nietzsche lists three areas of development to Mebrleben into which pity destructively intruded in on him, stating that its intrusion was nothing short of destructive ("geradezu zerstörerisch.") In his notebooks he says that he

\footnotetext{
${ }^{3}$ We do not read about Christianity as a curse until the last section of AC but also in The Will to Power Nietzsche writes that "the god on the cross is a curse on life, a signpost to seek redemption from life" (WP 1052, standard edition), and perhaps this thought of Christianity as a curse is where he derived the subtitle of AC of cursing Christianity in return.

4 Nietzsche's hopefulness that with $\mathrm{EH}+\mathrm{AC}$ he would finally be heard faded, and in mid-December he wrote to his editor Heinlich Köselitz that a tragic catastrophe of his life began for him with Ecce Homo, and he turned to writing Nietzsche Contra Wagner in the hope of communicating an understanding of himself as the psychological antithesis of Wagner, setting aside for a bit seeing to the publication of Ecce Homo, (KSB, 8: 1192). A onetime subtitle for Ecce Homo was: „Ecce Homo, oder ein Psychologen Problem: Warum ich einge mehr Weiss, " (KSA 14: 465), and the final subtitle of Nietzsche contra Wagner was "Aktenstücke eines Psychologen" although it is cited with the same subtitle as the early subtitle for Ecce Homo in his letter to Naumann of December 17 (KSB 8: 1193) to bring it into line with The Case of Wagner's subtitle, "A Musician's Problem." Nietzsche would seem to have lost hope that his complex and exceptional psychology could be understood by what he wrote in Ecce Homo, but today we have the science of the inheritance of epigenetic alterations and of the epigenetic evolution of culture, and these can provide a framework for interpreting it.
} 
classifies pity under the general category of being a kind of brutality, (KSA 13, 22 [28]). His argument that pity is decadent is that it was because his evolution of Mehrleben was the overcoming of the universal hostility against life that characterizes pity, that pity destructively intruded to stop him from what he was doing. It recognized and identified with its destructiveness in the state he was trying to overcome and tried to stop him. Without the universal platform, his knowledge claim that pity is decadent is unsupported. What was Nietzsche's extraordinary insight into the Machiavellianism of pity that his exceptional experience gave him? ${ }^{5}$

Ecce Homo/Wise narrates how Nietzsche inherited life on the "lowest rung" from his father and how he evolved himself autogenetically to Mebrleben using psychological disciplines (such as in Wise/4 and Wise/5), which would seem to be a sui generis development, but he makes universal claims based on it. It can only make sense that it does if there is something universal involved in that evolution. It is a mystery how he is engaging something universal. Andreas Urs Sommer writes on this point with understandable exasperation:

This prospective-retrospective double-examination concerns not only Nietzsche's own coming and his future but also the course of world history as a whole: EH considers a retrospective look on a history of decline of culture and wants to look out on the prospect of a promising future, which will be determined by the revaluation of all values. In the exemplary self that speaks in $\mathrm{EH}$, not only the individual past and future condense into a Dionysian present, but world history altogether should, so to speak, find [there] its needle eye, which according to the identification of the last chapter, considers itself to be a Destiny (Sommer, 327. Author's translation).

Sommer is right to be skeptical, but his point can be answered, in part readily so. Despite the project's universal title "Revaluation of All Values," the only values being called into question, and the only counter-values Nietzsche proffers as being an exemplary "I", are the values of Christianity. Nietzsche's revaluation project begins autobiographically within the scope of his "double descent" from the lowest and the highest rung on the ladder of life; he explicitly states in Wise/1that it was the repetition of the pattern of decline into decadence to recovery to health and then again relapse to decline that put him in the position to revalue all values. Pace Professor Sommer, the revaluation does not cover all of world history, which would be nonsense just as he is thinking it would be, but only a part of it. The revaluation covers a limited field: it is a study of values per their etiology in a specific psychopathological relationship to life of the vengeful hurting and crippling of it so as to stop it from becoming more. The more difficult question is how could Nietzsche's evolution to Mebrleben from the terminus a quo of the "lowest rung" on the ladder of life inherited from his father be this universal? How was the experience of decline and recovery to health the universal? His inheritance from his father must have a sui generis component, but also his self-overcoming must have engaged the universal, so that the universal in the culture recognizes itself in him and destructively intrudes on his self-overcoming, as in the case of the intrusions of pity in Wise/4, and he in turn recognizes the universal, as in the case of his understanding of the psychology of Jesus in AC 28-40. How can the inheritance

${ }^{5}$ KSA 13 32[4]: "Der Macchiavellismus der Guten, ihr Kampf um die Macht, ihren Mittel, zu verführen, ihre Klugheit der Unterwerfung." 
be both? The question falls within the theoretical framework of the theory of the epigenetic evolution of culture and paternal transgenerational epigenetic heritability.

Stated simply, the idea of the epigenetic evolution of culture is that new evolution speeds up rapidly after geo-physical calamities because epigenetic mechanisms come into play to accelerate it, as much as by 1,000 times the rate of selection of random gene mutations (Ward, 2018). Nietzsche's critique of Christianity is nothing if not the allegation of unspeakable calamity in our species that is steadily bringing on the decline of life by a chokehold on it: Christianity's instincts are hostile to life, as he cites them in AC/30: it thwarts the will to power in developing life to become more. But we seem to need it. GM III 28 suggests that we would succumb to suicidal madness without the psychological relief valve of finding to blame and the ascetic ideal that redirects blame to guilt. So, what could have happened that pushed us to this grim set of alternatives?

Suppose that epigenetic evolution in the aftermath of a geo-physical calamity set up the psychopathology of Christianity. Christianity's compulsive chokehold on the development of life could only have evolved as an adaptation because of a calamity and in a population that offered no other options and so was selected for, as in a remnant population from a near extinction event. A possible scenario is as follows. The Abrahamic religions originated in Anatolia some 4,000 years ago not far from the birthplace of agricultural civilization several thousands of years before, and that earlier event coincided with a near extinction event known as the Younger Dryas cooling event which may have been caused by a comet impact - that hypothesis is now mainstream science as of this writing but remains short of settled science. Perhaps the Roman occupation of Judea was a further traumatic event that affected the same already traumatically affected region of the epigenome and Christianity was the result. Christianity must have an etiology in trauma because it is so pathological, how else could it have evolved? The culture of revenge arose and set itself across the natural process of the evolutionary development of life because we have been subjected to ancestral trauma from geo-physical cataclysm which imprinted on the epigene of the remnant population and which is conserved to today. It is my speculation and not Peter Ward's hypothesis that traumas from ancestral cataclysms are conserved in the new behaviors and novel intelligences that subsequently evolve by epigenetic change, but if trauma from the cataclysm became imprinted but was not conserved, why did the new behaviors and new intelligences continue on instead of our reverting back to a precataclysmic state? Maybe the psychopathology of the Spirit of Revenge as we read about it in Z: 2 "On Redemption" evolved as novel mental life in the aftermath of an ancestral trauma and became steadily worse as variously reinforced by later traumas and the simple feedback loop of culture reinforcing itself and is conserved to today. Sommer raises the question how it is even possible for psychology to appear that pathologically thwarts evolution to begin with in his commentary on $\mathrm{AC} / 7$ 173, 10-15, and I suggest the answer is along these lines. The possibility opens on to the question of whether there has been epigenetic conservation of imprint by ancestral trauma on us in other streams which are also giving rise to culture of a pathological stranglehold on life as the sole way to survive rather than face the trauma. ${ }^{6}$

${ }^{6}$ See my uploaded YouTube video lecture to Zhejiang University, School of Sociology/Marxism from December, 2019:

"The Marx-Freud Synthesis and the Etiology of Domination in Epigenetic Evolution" hosted by Professor Zhang Guoqing, Director of the Centre and Distinguished Professor of the University. 
F. W. Nietzsche was as much an heir of Christianity as was K. L. Nietzsche and there is our universal element, but something changed in how it passed to F. W. Nietzsche in what was suigeneris in the inheritance, and from what he tells us and what we otherwise know, the sui generis factor in the inheritance was an epigenetic variation. Research into paternal effects on transgenerational epigenetic heritability has been flourishing in recent years, making this scenario increasingly plausible, (Rowold ED... Grabe HJ, 2017; Xu Xingyun... Wan Bo, 2021). The Paternal Origins of Health and Disease paradigm, POHaD, was recently introduced by Adelheid Soubry to fill in this gap, which has focused on maternal transmission until now. The variation may have been due to trauma to $\mathrm{K}$. $\mathrm{L}$. Nietzsche because of his deteriorating brain disease, or other related causes, which affected germ-line cells, which then would mean that every cell in Nietzsche's body would have been affected. The possible causes of K. L. Nietzsche's breakdown are covered in Daniel Blue's micro-biography. My solution to the universality problem raised, or re-raised, by Sommer is that because of an inherited variation from his father, Nietzsche's engagement of his father was also and by way of an engagement of the universal in the culture of Christianity as selected-for epigenetic coding. What was sui generis in the inheritance was an overlay and furtherance of the same trauma induced profile coding for the life-hostile tendency of Christianity that first evolved as novel intelligence in the aftermath of a near extinction event and because of it. In other words, extraordinarily, Nietzsche selfovercoming to Merbleben was evolution out of the ancestral and historically conserved epigenetic coding. So we must ask: in the case of Wise/ 6 and the psychological type of Jesus in AC 28-40, is Nietzsche "projecting" his sui generis psychology onto Jesus or had he, by dint of the extraordinary effort of self-mastery he relates in the chapter, successfully mastered the universal in himself (that the personal had become for him) so as to have become capable of an analytical study of the psychology of Jesus who shared that universal? Was it not to put before us that his study of the values of ascent and decline was this study of the universal in himself come to consciousness in him and overcome by him as the universal why he wrote Ecce Homo? - just as he says, perhaps not in so many words but it is in the text? So, there is no "needle eye" which the revaluation runs through of the "exemplary Nietzsche"; the revaluation was always running through the universal in him and being overcome as such, and there is no faulting him for being exemplarily unless it is a fault to evolve in exemplification.

Nietzsche denied that he was a Darwinian, and he was not a Social Darwinist (EH/Books/1), but the argument against pity at $\mathrm{AC} / 7$ certainly reads as along Social Darwinist lines: pity preserves the weak; the preservation of the weak goes against the law of evolution, which is the law of selection, therefore we should not pity. We read a similar point in EH/Destiny/8 that the good person sides with what ought to perish and crosses the law of selection. But Nietzsche nowhere says that the law of selection being crossed is Darwin's law of natural selection; his idea of evolution is not the idea of survival of the fittest. As he says in AC/3, humanity is an endpoint, by which I take him to mean that no one is "fit" and that there are no "fittest." Evolution for Nietzsche means life becoming more as per will to power, and his critique of pity is that it preserves what will to power selects against. Still, just to note, will to power is a natural law of evolution in Nietzsche, and Sommer in his commentary on these lines (KSA 6, 173 10-15) criticizes Nietzsche for committing the naturalistic fallacy of deducing a morality from what is naturally given: selection for or against as being a value claim is a fallacy (Sommer, 56). But we can ask 
whether evolution can make a normative claim on us without its being a moral claim. Briefly, I would seem to be subject to the claim that I should evolve. Even though there is no "why?" behind evolution's claim, the intuition of it as a claim on me is very strong, and the more so as I apprehend how far I am given over in the direction of my intimate weaknesses.

Although critical of Nietzsche for his anti-socialist views, Martha Nussbaum recognized that his critique of pity is quite nuanced and that he is defending a pro-mercy tradition as non-vengeful (Nussbaum, 156). Unlike pity, mercy is not an attempt to thwart the law of the will to power. But pity is revenge (GM III: 14), and as we read in Z: 2 "On Redemption," Christianity is vengeful and trades on a self-deception, which it promotes about itself, disguising its vengeful acts beneath the "good conscience." Morality, as we learn from the title of a book for UAW that appears in three of the six plans we have for it, is a catastrophic form of ignorance about ourselves (Montinari, 100). This is part of pity's Machiavellianism. Pity seeks to vengefully hurt and cripple life by thwarting the will to power. In the three cases in Wise/4, Nietzsche's evolution to Mehrleben provokes intrusions of the morality of compassion, but as we will see, they were anything but selfless acts. The intent of pity is to preserve the unfortunate happenstance because it will weaken the species by preserving it, but how will it weaken it? It is only weakening in the setting that that happenstance is selected against inasmuch as it is being selected to be overcome by will to power - not all such and not in all ways, but in some ways that become part of our evolution to Mehrleben. Pity interferes just to be vengeful against the development of life, lying then that it is being moral in doing so to conceal its vengefulness. This is the point of Nietzsche's critique of socialism in AC/57 et seq. His critique of equal rights is not that equality is nihilistic based on the premise that because some groups are lower and others higher, equalizing always leads to lowering. This is how the far right is reading Nietzsche, but it is a misunderstanding and one suspects they are reading him that way because they are reading him through the lens of Heidegger: "Heidegger's my guy" said Steve Bannon. 7 Nietzsche's critique is about pity vengefully interfering with what will to power has selected against, and it is not about mercy which is not vengeful, and mercy can cover some of the same field. If we are not merciful here, then we know that we are dealing with bias, at least the bias of humanism ${ }^{8}$

Nietzsche's philosophy of evolution is contained in summary in autobiographical form in Ecce Homo in Wise/7. It is not complete there but one has to consider that he wrote it as an autobiographical introduction planning to follow up in UAW, and the theoretical thinking is complete in the Nachlaß. There we learn that will to power can only manifest

\footnotetext{
7 “Searching in Europe for Glory Days Gone By", by Christoph Scherermann. Steve Bannon interview with Der Spiegel, October 29, 2018. http://spiegel.de/international/world/stephen-bannon-ties-rightwing-revolution-in-europe-a1235297.h. Web. Last accessed June 7, 2021.

${ }^{8}$ Nietzsche says that if we are not strong enough for a given stimulus, it cannot serve to be such. In The Case of Wagner, paragraph 6 he says that "sickness can be a stimulant to life: only one has to be healthy enough for this stimulant"; in $\mathrm{EH} / \mathrm{Wise} / 2$ he tells us that he is strong enough to make things turn out for the best; in Z: 1 "The Adders' Bite" he says that one must be "rich enough" to take the guilt upon oneself, repeated in EH/Wise/5 that it can be good fortune to be wronged, only one must be "rich enough" for it, and in EH/Clever/ 6 that he is strong enough to take upon himself the questionable and dangerous and become stronger. It is falsification to attribute to Nietzsche the open-ended position that we should look impassively on suffering not in use by will to power to evolve. Sarah Kofman attributes this very uncharitable position to Nietzsche on this point in her commentary on EH/Wise/8 that Nietzsche would have looked on the sufferers of Auschwitz without pity, but she does not ask about mercy (Kofman, 263-269).
} 
itself against a resistance, that it seeks resistances. We also learn that resistance must be equal and that the will to power interprets what an equal resistance is, (WP 656, 688; KSA $12,2[148]$, and a little further on in the same notebook he writes, 'One mustn't ask: 'So who interprets?" - instead, the interpreting, as a form of the will to power, itself has existence, (but not as a 'being'; rather as a process, as a becoming) as an affect" 2[151], (RB, 91).We find these ideas in Wise/7, except for the important idea in the notebooks that the will to power interprets what is equal in the resistance, although it is implied in Wise/7 as how else would you know who the equal opponent was? The act of interpretation of an equal opponent is itself just a means to become master of something; interpretation itself is a form of the will to power. The theory is that we cannot stop it: the will to power in life will drag us to pathways contrary to the happiness of self-preservation, pathways leading to an unhappy and sorrowful rendezvous with devilry and devilment in life. ${ }^{9} \mathrm{We}$ are embedded in this law, and there is room for mercy but much opportunity for pity.

Nietzsche's critical work in The Antichrist and the critical work planned for books II and III of UAW is kulturkritik on how we are so very not settled into the law of our evolution. Individual will to power selects against a resistance of unfortunate happenstance, perhaps one it engineered, by sizing it into an equal resistance and mastering it to evolve, but pity intrudes destructively to thwart will to power to satisfy its vengefulness against life.

Nietzsche's autobiographical account in Wise/4 is of his experience of the intent of pity to vengefully cause hurt and crippling to him as he had been on contrary pathways to Mehrleben and pity had caught up with him and began intruding to stop him. But what is Nietzsche's wisdom, what about his critique of pity means setting it in the chapter "Why I am So Wise?" It is an important question because Nietzsche's wisdom accounts for how he knows that he is on the pathway of Mehrleben and overcoming vengefulness, and so also how he knows what pity was trying to interfere with.

Nietzsche's wisdom is different from any philosophical wisdom that came before in that it relates to the acquisition of empirical knowledge of how to grow and develop life in ourselves. In the chapter "On Famous Wise Men," in Z: 2, Zarathustra instructs the wise men, so called, that spirit is "life that cuts into itself, out of its own pain it itself adds its own knowledge ("das eigne Wissen"). Both Wise/4 and Wise/5 make knowledge claims along these lines, so wisdom as knowledge is a reinforced idea, but here we only need to study. Wise/5's knowledge claim about the efficacy of the psychology of blaming one's own innocence as a way to "bite down hard" on the compulsion to retaliate when facing being wronged. Bearing a heavy guilt is one of the three cases in which pity destructively intruded on him.

To control moral aggrievement at being wronged while in the right, Nietzsche devised the psychological exercise of blaming himself for the wrongdoing. But what is the point of controlling vengefulness? Is it just not to be vengeful? Is that the revaluation? I would say not. The underlying psychological idea here is that vengefulness "burns up" aliveness, as he tells us in Wise/6. I do not know if we have ever had a psychology of aliveness before or since: it is Nietzsche's key insight. By controlling vengefulness he created Mehrleben, which is how he got from his death in life to life; just as in the opening of Wise/4, in Wise/5 he is "also" like his father, his starting point. Nietzsche's self-knowledge of his

${ }^{9}$ On the will to power as a contrarian pathway of devilry, see KSA 11 26[243]. 
overcoming is alert in all three of the cases of pity: destructive intrusion into his great destiny, into his solitude of one who has been wounded and into the privileged right (his emphasis) to bear a heavy guilt. This is the foundation of his knowledge claim about pity in Wise/4 that in intruding it is decadent. It is because he knows what pity is siding with in himself, he knows that it is the revengefulness he is trying to overcome by means of this discipline, and he perceives pity's siding with it against life, compulsively intruding in vengefulness, no boundaries. In $\mathrm{AC} / 7$ he tells us that pity is a depressant, that it multiplies a loss of strength and thus creates further suffering, suffering beyond and above the suffering of vengefulness to his life. He perceives pity's gesture of added suffering to his aliveness in the three cases. Pity is Machiavellian in trying to get him to stand down from his effort of self-overcoming by multiplying his suffering of weakened life over and beyond the suffering of vengefulness thus to increase the suffering he has to overcome. Pace Sommer in his commentary, I do not think this is "medical jargon" nor do I understand what his point is in saying that; literal usage is intended (Sommer, 51). All this in Wise/4: the interaction between Nietzsche in his knowing self-overcoming of his inherited vengefulness by means of which he was creating life in himself per the agency of will to power in life, and pity's destructive intrusion, vengefully trying to get him to stand down by the stratagem of multiplying suffering to make his self-overcoming unbearable and futile to the end that life will not evolve, must be the most complex psychological interaction we have on record, or that matters at any rate, and very much worth studying. It was an encounter with madness. Cultural psychology is the hinge pin for the problem of evolution; there would be no reason for Nietzsche's kulturkritik otherwise.

Nietzsche says that his experience gives him a right ("anrecht") to a general mistrust of the self-less drives so called. He is generalizing from his experience but he has a right to this generalization, he says, that is, he is not guilty of the fallacy of generalization. This claim to universality must lead us to ask what in his experience was already general, and I have sought to address that problem above. Wherever and whenever pity is agent, it is working across will to power in the evolution of life to become more, thwarting it in vengeful hatred against life under the deception of the good conscience. His generalization is: "Mitleiden überredet zum Nichts!” (AC/7).

The first case Nietzsche cites of pity's destructive intrusion into his development of Mebrleben was intrusion into his "großes Schicksal." We may imagine that someone had said to him something along the lines: "Poor man, you should not so take the whole weight of the world on yourself." The gesture seems like compassion, but Nietzsche says that he recognized that it was an attempt at destructiveness. What was Nietzsche referring to as his destiny and how did pity's interest in getting him to stand down from it expose it in its psychology of being lebensfeindlich?

Related to Nietzsche's idea of being a person of destiny ("Schicksal") is his idea of being a person of calamity/catastrophe. He describes himself as "Mensch des Verbängnisses" in Ecce Homo, Chapter 4, "Why I am a Destiny," and we also find this idea in his drafted letter to Georg Brandes from early December, 1888 (KSB 8: 1170) where he talks about Ecce Homo as having to appear before The Antichrist. He says there that the last chapter of Ecce Homo gives a foretaste of the war against Christianity and its destruction, and that he appears there as a "Mensch des Verhängnisses," full of fateful consequences for the history of the world. But Nietzsche had introduced us to this idea in Wise/1 in the opening statement of 
the character of his existence. There he speaks not only of the happiness of his existence but says also that his existence it is a Verhängnis, that his happiness lies also is his being an augur of an undoing and remaking of things. He adds this to the opening sentence of Wise/1 about his happiness because he is making the case of his ethos appeal to lead in the task of human self-overcoming, as per the stated purpose in the foreword of Ecce Homo, to confront humanity with the heaviest demand ever made on it. Here in the opening of Wise/1 we learn about him in that role. He is a "Mensch des Verhängnisses" in exposing us as beings of vengefulness, beings given over to an opposite disposition to life than is needed for its growth and development made into a culture, and hoping that by provoking this "crisis of conscience" he can dislodge its grip. How did he come into this position, what was his happiness and how was it also this?

Nietzsche tells us that it was his happiness/good fortune to encounter the highest opposition to life, death in life per his inheritance from his father, ${ }^{10}$ and that it was also this happiness that made his existence a Verbängnis. Both Nietzsche's happiness and his being a "Mensch des Verbängnisses" are composed in the form of a riddle. The riddle of his happiness/destiny becomes: "Whose happiness/destiny is death in life?" as it would seem unimaginable for this to be so and in need of an answer. ${ }^{11}$ The solution to the riddle is in the nature of the will to power: the highest opposition to life can become the highest happiness because the will to power does just this: it seeks resistances to develop to become more, in the case of life, to Mehrleben. The idea of happiness here is pointedly not that of the townspeople of Motley Cow in Zarathustra's "Prologue" but follows the definition of happiness in $\mathrm{AC} / 2$, as the feeling of power increasing, that resistance to life is overcome. It is because the resistance of the highest opposition of death in life in his paternal inheritance was overcome that he has the highest happiness. But what in his inheritance has been overcome: something merely sui generis or the universal in Christianity? I have suggested that we can account for how the universal in Christianity became the personal because of the anomalies in his paternal inheritance. Nietzsche's becoming a "Mensch des Verhängnisses" was also on account of his engagement with his paternal inheritance of extreme weakness and extreme vengefulness spawned by weakness and his self-overcoming evolution to Mehrleben, but because it was an engagement with the universal, it was the overcoming of Christianity to Mehrleben to its precise opposite. Pity's: "Poor man, you should not so take the fate of the word on yourself" was not a caring

\footnotetext{
${ }^{10}$ In a variant to the epigraph (On this perfect day...") Nietzsche wrote a second a paragraph that concludes: "the highest prize life can win is that it also opposes us with its highest opposition” ("aber das ist die höchste Auszeichnung des Lebens, daß es uns auch seine böchste Gegnerschaft entgegenstelle” KSA 13, p. 614, 1. 7-8). Nietzsche engaged the extreme terms that frame his philosophy of evolution; he faced a unique opposition and achieved a unique development over it. In all three narratives of his evolution to Mebrleben in Wise/4 that brought pity on against him, he was facing this highest opposition of death in life, a deepmost intimate vengefulness. Had he retained this second paragraph, this would have been the last sentence we would have read before beginning with Wise/1 and the riddle of his happiness, which was also how his existence is a Verbängnis. Both his happiness and being a Verbängnis evolved from facing and overcoming the highest opposition, which could only refer to his inheritance of death in life from his father, as I have combined them in the statement above.

${ }^{11}$ His remarks about his father and having not been given life by him are not remarks aside. Among his subtitles for Ecce Homo (these appear in the KSA directly following the ur-Ecce Homo) is one of unusual noteworthiness, it reads: "In media Vita. Aufzeichnungen eines Dankbaren." But the Latin phrase is shortened from: "In media vita in morte sumus," a saying from ecclesiastical literature set in Gregorian chant by John Sheppard and a favorite saying of Martin Luther's: "In the middle of life we are dead." Combined with the subtitle, the whole poses a variant of the riddle of his existence in Wise/1: How can one be grateful for death in life? (KSA 13 24[2]). The key to Nietzsche's psychology, identified as having the character of a problem in other subtitles, is just this question, and his philosophy is the answer to it.
} 
thought about his well-being but an attempt to get him to stand down and be resigned to the culture of vengefulness that would victoriously keep its stranglehold on life. Because his self-overcoming is a knowledge state, he can perceive that pity is siding with the deepmost vengefulness associated with his paternal inheritance and against his will to power. Here, and in all three cases, Nietzsche caught pity red-handed in trying to thwart his development of life. That Nietzsche is this "Mensch des Verbängnisses" is the claim most relevant about himself in Ecce Homo per his critique of Christianity in The Antichrist because it refers to his overcoming of precisely Christianity. His Mebrleben is Christianity's precise undoing, as there are other paths to reach Mebrleben that are not by way of the overcoming of vengefulness. He overcomes the thoughts and feelings of vengefulness that at each step he knows belong to Christianity and that oppose his overcoming but from out of which opposition he creates life. He became the ultimate threat to Christianity in that it marks the first time it has been challenged to face itself, and its assault must have been intense. This idea of how his great destiny is Mehrleben as overcoming the universal lebensfeindliche Tendenz in Christianity is what makes Ecce Homo a preparatory work to The Antichrist. ${ }^{12}$

The second case Nietzsche cites of pity's intrusion is the case of his retreat to solitude to recover from being wounded. He might be referring here to his second practice in warfare in Wise/7. There he lists four practices in warfare, and as his second practice he says that he attacks causes in which he is sure to stand alone and without allies and so he alone is compromised, and that to be compromised singly in warfare is his criterion of right action. This is another revaluation: to be compromised as right action. The idea of being compromised in warfare means relapse back into the thoughts and feelings of vengefulness and vindictiveness in exhaustion from will to power pushing too hard against them. Being compromised becomes a criterion of right action because it signals that the maximal effort of self-overcoming has been put forth. To be compromised in the struggle to evolve Mehrleben is a kind of wounding, whence the military metaphor here in Wise/7. Wounded in warfare, solitude becomes necessary for Nietzsche as he can no longer control his firstorder reactive psychology and must withdraw from exposure to the provocations to react. He knows that this is the meaning of his solitude. What then is the interest of pity in intruding in this situation with its "Poor man, you just need to get out and around people, and then you will feel better" or some such as must be what he is alluding to as pity's intrusion. Its advice is exactly the opposite of what is needed for his recovery and it ensures that recovery will not be realized; its intent is to see him further harmed. Again, pity is on the wrong side of will to power's life-creating effort in him, heartlessly Machiavellian in its attempt to subvert him.

\footnotetext{
${ }^{12}$ I cannot see how Professor Conway's view of the relationship of EH to AC as being "largely instrumental" (see note 1above) is sustainable in view of this argument. In the drafted letter to Brandes of early December where Nietzsche is at his most militant, the censorship issue is not raised and the emphatic identification of the relationship of EH to $\mathrm{AC}$ is as a "Mensch des Verbängnisses" to what is ahead in the undoing and remaking of the world about which EH/4 gives us a foretaste. Professor Conway sees in the drafted latter to Brandes a "delusion of geopolitical grandeur" (Conway, 16 n. 9). The question for philosophy is whether the unmasking psychology of Christianity as maintaining a vengeful chokehold on the development of life and mendacious about doing so is true and whether Nietzsche's knowledge claim in EH that he is "décadent zugleich und Anfang", that he knows both (Wise/1), can be reconstructed as sound epistemology that grounds it. Whether he developed an associated ego of aggrandizement per its being true would seem to be irrelevant.
} 
Finally, Nietzsche says that pity reached destructively into his right (his emphasis) to a heavy guilt. We must turn to Wise/ 5 for clarification of the meaning of bearing a heavy guilt and how it is a privileged right.

What Nietzsche learned in Wise/5, a joyous knowledge for the lion willed, ("Erkennen: das ist Lust dem Löwen-willigen" Z: 3 "On the Three Evils" 16), was that blaming himself for the wrongdoing of another while being in the right is how to overcome moral aggrievement at being wronged and master the thoughts and feelings of retaliation against the wrongdoer. The idea of blaming one's own innocence as the way to control moral aggrievement at being wronged while in the right is a core idea of the revaluation: Wise $/ 5$ looks back to the text of "The Adder's Bite" from Z: 1 and looks forward to The Antichrist, section 57 "wrong lies not in unequal rights but in the assertion of equal rights" - assertion of an equal right not to be wronged is what generates the other's wronging act as a wrong, which, an sich does not have moral properties of course. ${ }^{13}$ His self-discipline is to not consider himself as being equally entitled not to be wronged: this is the connection between retaliation for wrongdoing and the assertion of equal rights being both far from him. Thus he says that he "never lives among his equals" meaning that he stays in control of the feeling of equal entitlement not to be wronged because it otherwise leads to the imputation of wrongdoing to whatever is the an sich issue in question. He is thus able to elide the so-called "wrongdoing," and so the feelings and thoughts of retaliation that go along with it, by denying equal entitlement not to be wronged. The psychology of moral aggrievement at innocence wronged is at the heart of Christianity: Jesus's punishment is maximally unjust by reason of Jesus being perfectly innocent, as perfect innocence leaves no room for guiltiness that could be deserving of punishment. The psychology of moral aggrievement at innocence wronged is maximized in the thought of perfect innocence punished. For Nietzsche, Christ on the Cross is a curse on life in the form of maximal moral aggrievement at the injustice of the world, although not in Jesus's thinking, as he makes clear in AC/40. The true god come to earth would find his innocence already blameworthy as meaning liability to being wronged: "a god come to earth ought to do nothing whatever but wrong: to take upon oneself not the punishment but the guilt - only that would be godlike" in Wise/5 (Hollingdale translation), and "devise for me the love that bears not only all punishment but also all guilt" in Z: 1 "The Adders Bite" (Parkes translation). Blaming oneself although innocent for the wrongdoing of another to oneself while in the right is a second-order psychological strategy employed consciously to rein in a first-order compulsion to retaliate for the wrongdoing and punishing the wrongdoer. It is critical to recognize that when Nietzsche speaks of bearing a heavy guilt in Wise/4, he

\footnotetext{
${ }^{13}$ Sommer would seem to miss the point of this line about the agenda of the anarchist in inflaming vengefulness in the working class by encouraging the assertion of equal rights in his commentary on AC/57, KSA 6 244, 28-32, (Sommer, 279). He does not there bring the line into the context of $\mathrm{EH}$ Wise/ 5 where it is introduced. In his commentary on Wise/5 he reads the line at KSA 6 271, 6-8 that Nietzsche does not live among his equals (and unlike Jesus aspires to take upon himself the guilt and not the punishment) as messianic, (cf. also Sarah Kofman's commentary on this section, which is similar in seeing a messianic ego in being without equals, (Sommer 380f; Kofman I $236 \mathrm{ff}$ ). Sommer's commentary on the summation line in Wise/ 5 about a god come to earth doing nothing but wrong at KSA 6 271, 28-32 comparing Nietzsche's position to Callicles in Plato's Gorgias, is a mis-comparison, as Nietzsche's Dionysian God blames himself as always in the wrong as per not imputing wrongdoing, which is not Callicles's thought, (Sommer, 381f). Still on Wise/5, Sommer does not reference Z 1: "The Adder's Bite" where we find listed a number of early stage attempts to master retaliation for a wrongdoing ("a wrong shared is half right" etc.) prior to the terminal stage of doing nothing but wrong, the same summative line there as in Wise/5, and the presence of these more elementary psychological exercises establish the idea that the god who does nothing but wrong is at the terminal point of such and signifies evolution and not an egomania of messianism.
} 
is aware of what the psychological compulsion is that he is controlling by doing this, namely, moral aggrievement and retributive punishment.

In Wise/4 then, Nietzsche says that pity intruded destructively into his privilege to bear a heavy guilt. Someone must have said something to him about it, perhaps something such as: "Poor man, you should not so blame yourself for everything," all too ready with advice seeing him suffer beneath taking on the guilt. Pity was trying to multiply the suffering to his life of vengefulness and to the end of getting him to stand down from the attempt to control it and succumb to moral aggrievement at being wronged and capitulate to the rule of life being thwarted in becoming more. So whose side was pity on? The wrong side, which is Nietzsche's point. He had caught pity red-handed in its vengefulness against life, siding with the effect of vengefulness and brutalizing him by trying to intensify his suffering to so overwhelm him that he would pull back from the effort at Mehrleben. So much for pity's supposed "selflessness": its purpose is to serve itself, it gluts itself on vengefulness, and it is merely a self-indulgent vice. No one who is not a decadent would consider pity a virtue because it is entirely something self-serving to the decadent and meaningful only to him.

Nietzsche calls Christianity a vice in AC, and in his drafted letter to Brandes of early December, 1888 he says that the law against Christianity should read: "war to the death against the vice, the vice is the Christian." 14 Nietzsche speaks of noble virtues, but he is more just using the language of edification than building moral thinking. The noble virtues seek the ascent of life, but he offers nothing by way of what makes them noble other than that they do so. Actual moral thinking about the value of ascending life would have to begin with the premise that ascending life is intrinsically good, and I don't think Nietzsche believed in intrinsic goods, so he is really just talking in a circle, but it is rhetoric after all. Still, we can proscribe against the vengeful hatred of life in pity without re-positing morality or a theory of virtue by making it normative to evolve without arguing that it becomes so as an inference from the premise that the evolution of life is good.

Nietzsche's theory of evolution only applies to individuals; he could not have written more unambiguously on this point. He wrote to Brandes that the wars to come between the healthy (Nietzsche and development of Mehrleben) and the sick (the pitying who vengefully attack the will to power by intensifying the feeling of suffering so that the healthy will give up) will not be fought between the "absurden Grenzen" of race nation and class but in "eine Individuen Gegensatz-Bildung" (KSB 8: 1170). " Fatherland is "the furthest thing from us" Nietzsche writes "it goes against the conscience in us to be patriots," (KSA 12 7[27]. ${ }^{16}$

\footnotetext{
${ }^{14} \mathrm{KSB} 8: 1170$

${ }^{15}$ Also Ecce Homo, Why I am a Destiny,” section 1, and „Die großte Politik“ KSA 13 25[1]. In this draft of a letter to Brandes Nietzsche is clearly having a very active daydream of his war on Christianity, imagining that The Antichrist, which he calls an "agitation edition," will be printed into a million copies. But is this mania of geopolitical grandeur or just fantasy aggression, and what is fantasy in it and what is reality? Was he insane to want to incite a war on Christianity? The answer is that if in fact he had drawn back the curtain from the corruption „Verdorbenheit“ of humankind - not a moral judgment at all - as he says in AC/ 6 then he was not out of touch with reality, and unless we can claim being in touch with the same disturbing reality and make the case that there is a normal way to be so, talk of Nietzsche's insanity is out of the question. Was he deluded in believing that he could incite a war of the healthy against the sick by what he says in EH $+\mathrm{AC}$ ? Too soon to tell.

${ }^{16}$ See also KSA $127[47]$.
} 
There is order of rank, but it is between individuals. ${ }^{17}$ So where would that leave the likes of Donald Trump? Is he in the Individuen-Gegensatz-Bildung or not? There is no basis for an answer to this question in Nietzsche's work because it concerns Christianity and the study of a life destructive pathological psychology in Christianity, pity as thwarting evolution. To answer the question about who are Nietzsche's "werthvollen Individuen" comprehensively, we would have to work out the same elements in a kulturkeritik of authoritarian culture: is domination life destroying and how do we know that it is? If, that is, we can know it at all, as Nietzsche's knowledge that Christianity vengefully strikes out against life follows his own self-study, and there was a unique situation for that study, and so we would need one similarly unique to ground the knowledge claim that the psychology of domination is intending to be life destroying and how it is so. So actually, regarding the question whether authoritarianism is hostile to life like Christianity but just in a different way, if we are to be truthful to the limits of Nietzsche's work, we have to be agnostic. But as we said at the outset in criticism of Professor Sommer, Nietzsche's kulturkritik does not cover all of world history but is limited. But because we do know now that pity is lebensfeindlich, as Nietzsche perceived it to be so, those individuals who do not react to the development of Merbleben by trying vengefully to forestall it by pitying will be in the Gegensatz-Bildung and given over to the claim evolution makes on them to evolve to Mehrleben, but they will hold that claim autonomously and self-directedly in a culture of autonomy. (Trump who?) On this showing, Nietzsche's critique of pity and his revaluation of the individuals who reject it as being "werthvollen" can hold no interest for the far right.

To end with a note aside, the privileges Nietzsche owes to his father in Wise/4 and Wise/5 are acquired characteristics: in Wise/4 that he never aroused ill will in others and in Wise/5 that he never lived among his equals. These privileges follow from deliberate exercises of will to power and lead to Mebrleben as autogenesis, but are owed to his father indirectly, as he mentions him at the beginning of both sections. This is a critical point against an older reading of Nietzsche as holding to August Weismann's keimplasma theory - ahead of its actual announcement by Weismann - as insisted on by Friedrich Würzbach, but it is still worth noting today. If Nietzsche's evolution of Mehrleben was autogenetic it evolved in somatic cells, and if the Overhuman is the idea of a consolidation of acquired characteristics, as is suggested in Z 2: "On Redemption," he would seem to be thinking that acquired characteristics are heritable. The Overhuman is "eins dichte und zusammentrage," come to be out of the overcomings of unfortunate happenstance - as far as is possible and these will be acquired traits. This point spells the failure of trying to read biological racism into Nietzsche as it implies that he did not (pre) accept Weismann's barrier that acquired traits are not heritable, which we now know does not hold (Jablonka and Lamb, 2020). And although Heidegger rejected biological racism after WWII, he seems not to have rejected cultural racism - whence he has emerged today as the central philosopher of the global far right (Göpffarth, 2020) - but the point above about the Overhuman of acquired traits applies to cultural racism as well. If a trait can be evolved in somatic cells

\footnotetext{
${ }^{17}$ The topic of order of rank appears in the title plans for the Will to Power from the last plan from August 1888. In this plan, Nietzsche presents his positive philosophy in three chapters of book IV: 1. The Principle of Life ("Order of Rank"), 2. The Two Paths and 3. Eternal Recurrence (Montinari, 96). Nietzsche drafted quite developed notes for the chapters, these are at KSA 12 7[9] - 7[70], 8[1]-8[8], although there notes only for chapter one, The Principle of Life. He says that people and races merely form the body in which individuals full of value carry on the great process of development: "Man muß sich nicht täuschen lassen: ganz. so steht es mit den Völkern und Rassen: sie bilden den "Leib" zur Erzeugung von einzelnen werthvollen Individuen, die den großen Prozeß fortsetzen," (KSA 12 7[9]).
} 
and then carried and passed on through the germ-line and if the Overhuman comes out of acquired characteristics, she/he can be based on any cultural identity, as any trait identified and vaunted as having a distinctive value can be theoretically duplicated in the germ-line cells of any race or nation, or class. Nietzsche's philosophical biology leaves him quite useless to the far right.

\section{Editions of Nietzsche's Works}

eKGWB = Digitale Kritische Gesamtausgabe Werke und Briefe. Edited by Paolo D'lorio. Paris: Nietzsche Source 2006, http:/ / www.nietzschesource.org.

KSA = Friedrich Nietzsche. Sämtliche Werke. Kritische Studienausgabe in 15 Bände, Giorgio Colli and Mazzino Montinari, editors. Walter de Gruyter, Berlin/New York and dtv, Munich 1980; Nietzsche Werke, Historisch-kritische Ausgabe on CD ROM, 1994, Walter de Gruyter and InteLex, (ohne Kommentar, Band 14).

KSB = Friedrich Nietzsche. Sämtliche Briefe. Kritische Studienausgabe in 8 Bände, Giorgio Colli and Mazzino Montinari, editors. Walter de Gruyter, Berlin/New York and dtv, Munich 1986.

$\mathrm{RB}=$ Nietzsche: Writings From the Late Notebooks, Cambridge Texts in the History of Philosophy, Edited by Rüdiger Bittner, Translated by Kate Sturge, Cambridge: Cambridge University Press, 2003.

$\mathrm{WZ}=$ La volonté de puissance, Texte établi par Friedrich Würzbach, traduit de l'allemand par Geneviève Bianquis, Paris: Éditions Gallimard, 1995.

\section{Works Cited}

Blue, Daniel. The Making of Friedrich Nietssche: The Quest for Identity, 1844-1869. Cambridge: Cambridge University Press, 2016. 28-31, endnotes 108-110. Print.

Conway, Daniel. Introduction to: Nietssche and The Antichrist: Religion, Politics, and Culture in Late Modernity. London/New York: Bloomsbury Academic, 2019. 14-20. Print

Göpffarth, Julian. "Why did Heidegger emerge as the central philosopher of the far right?, Centre for the Analysis of the Radical Right, 23 June 2020 Web. Last accessed June 2, 2021.

Jablonka, Eva and Lamb, Marion J. Inheritance Systems and the Extended Evolutionary Synthesis, Cambridge Elements, 2020. Print.

Kofman, Sarah. Explosions I: De l'"Ecce Homo" de Nietzsche, Explosions II, Les enfants de Nietzsche, Paris: Éditions Galilée, 1992, 1993. Print.

Liebscher, Martin. 12: The Anti-Christ, in A Companion to Friedrich Nietzsche: Life and Works, edited by Paul Bishop. New York: Camden House, 2012. 340-360. Print.

Montinari, Mazzino. "Nietzsche’s Unpublished Writings from 1885 to 1888, or Textual Criticism and the Will to Power," in Reading Nietssche, translated and with an introduction by Greg Whitlock, Chicago: University of Illinois Press, 2003. 80-102. Print. 
Nussbaum, Martha C. "Pity and Mercy: Nietzsche's Stoicism," in Nietzsche, Genealogy, Morality: Essays on Nietzsche's On the Genealogy of Morals, edited by Richard Schacht. Berkeley and Los Angeles: University of California Press, 1994. Chapter 9, 139-167. Print.

Rowold ED, Schulze L, Van Der Auwera S, Grabe HJ. "Paternal transmission of early life traumatization through epigenetics: Do father's play a role?" Medical Hypotheses, 18 September 2017, 109: 59-64. Web. Last accessed June 2, 2021.

Sommer, Andreas. Kommentar zu Nietzsches Der Antichrist, Ecce Homo, Dionysos-Dithyramben, Nietzsche contra Wagner. Historischer and kritischer Kommentar zu Friedrich Nietzsche Werken, Herausgegeben von der Heidelberger Akademie der Wissenschaften Band6/2. Berlin/Boston: Walter De Gruyter 2013. Print.

Soubry A. "Epigenetics as a Driver of Developmental Origins of Health and Disease: Did We Forget the Fathers?" BioEssays. National Library of Medicine, Epub, 23 November, 2017. Web. Last accessed June 2, 2021.

Ward Peter. Lamarck's Revenge: How Epigenetics is Revolutionizing Our Understanding of Evolution's Past and Present. London: Bloomsbury Publishing, 2018. Print.

Xu Xingyun, Miao Zhigang, Sun Miao, Wan Bo. "Epigenetic Mechanisms of Paternal Stress in Offspring Development and Diseases," International Journal of Genomics, 19 January 2021, Web. Last accessed June 2, 2021. 